\title{
EARLY INVASIVE PRENATAL DIAGNOSIS IN HBsAg-POSITIVE WOMEN
}

\author{
P. M. GROSHEIDE*, H. W. P. QUARTERo $\dagger$, S. W. SCHALM*, R. A. HEIJTINK $\ddagger$ AND G. C. M. L. CHRISTIAENS§ \\ Departments of Internal Medicine* and Obstetrics and Gynecology†, Academic Hospital Dijkzigt and Department \\ of Virology $\ddagger$, Erasmus University, Rotterdam; §Department of Obstetrics and Gynaecology, Academic Hospital \\ Utrecht, Utrecht, The Netherlands
}

Received 5 July 1993

Revised 20 October 1993

Accepted 25 November 1993

\begin{abstract}
SUMMARY
From 1982 to 1989 , pregnant women in two large city hospitals in The Netherlands had serum samples screened for hepatitis B surface antigen (HBsAg). Infants of mothers found to be $\mathrm{HBsAg}$-positive received hepatitis B immune globulin immediately after birth and hepatitis B vaccine in the first year of life. Blood samples of infants were regularly tested for $\mathrm{HBsAg}$ and antibodies directed against HBsAg. A retrospective analysis of the pregnancy outcome in HBsAg-positive women who had invasive tests for prenatal diagnosis was carried out to determine whether amniocentesis and chorionic villus sampling (CVS) are risk factors for the intrauterine transmission of the hepatitis B virus. Amniocentesis was carried out in $17 \mathrm{HBsAg}$-positive women and CVS in one case. Only two women were $\mathrm{HBsAg-}$ and $\mathrm{HBeAg}$-positive. Prenatal diagnosis led to the termination of pregnancy for fetal chromosome abnormality in three cases. The remaining 15 pregnancies were uneventful; all infants were negative for $\mathrm{HBsAg}$ and developed an active immune response to the vaccine. These data suggest that amniocentesis in HBsAg-positive women constitutes a low risk for the intrauterine transmission of the hepatitis B virus, but definite conclusions in $\mathrm{HBeAg}$-positive women cannot be drawn.
\end{abstract}

KEY WORDS-Hepatitis B, amniocentesis, chorionic villus sampling, prenatal diagnosis, intrauterine infection, neonate.

\section{INTRODUCTION}

With increasing technical capabilities for more and earlier prenatal diagnosis, obstetricians should question the potential risks of invasive tests in hepatitis B surface antigen (HBsAg)-positive women.

Without prophylactic measures, the risk of perinatal infection among infants born to mothers infected with the hepatitis B virus (HBV) ranges from 10 to 90 per cent, depending on each mother's hepatitis B e antigen ( $\mathrm{HBeAg}$ ) status

„Present address: National Institute of Public Health and Environmental Protection (RIVM), Department of Infectious Diseases and Epidemiology, Bilthoven, The Netherlands.

Addressee for correspondence: Professor Dr S. W. Schalm, Department of Internal Medicine II, University Hospital Dijkzigt, Dr Molewaterplein 40, 3015 GD Rotterdam, The Netherlands.

CCC 0197-3851/94/070553-06

(C) 1994 by John Wiley \& Sons, Ltd.
(Beasley et al., 1977; Stevens et al., 1979). Up to 90 per cent of infants infected by their mothers at birth develop chronic HBV infection (Stevens et al., 1975).

Most HBV infections occur perinatally; infants are exposed to the virus during labour (Stevens et al., 1975; Gerety and Schweitzer, 1977; Lee et al., 1978). Presumably mother-to-infant transmission occurs from haematological leaks across the placenta and/or birth canal exposure to maternal secretions or blood (Beasley et al., 1982; Lin et al., 1987).

Early administration of hepatitis B immune globulin (HBIg) to the newborn infant is therefore important to protect the infant from perinatal HBV infection. Passive-active immunization, consisting of HBIg and hepatitis $B$ vaccine has been very effective ( $>90$ per cent) in preventing HBV infection among infants born to $\mathrm{HBsAg}$-positive 
mothers (Stevens et al., 1987; Schalm et al., 1989). However, some $\mathrm{HBeAg}$-positive mothers infect their infants before labour and delivery, i.e. during premature labour or threatened abortion (Ohto et al., 1987). These infants will not be amenable to immunoprophylaxis and any immunization programme is likely to fail. Hepatitis B virus is considered not to pass the intact placenta. Besides placental leakage due to uterine contractions, disruption of the placental barriers may also result from invasive tests such as chorionic villus sampling (CVS) and amniocentesis for early prenatal diagnosis of fetal genetic disease. The question arises as to whether health-care professionals should offer an HBsAg-positive woman prenatal genetic testing where there is a chance of infecting the infant with $\mathrm{HBV}$ in utero.

Because data in the literature are scarce, we retrospectively investigated the impact of early CVS and amniocentesis on intrauterine transmissions of $\mathrm{HBV}$ from $\mathrm{HBsAg}$-positive women to their offspring.

\section{PATIENTS AND METHODS}

In 1982 a multicentre trial was started in The Netherlands to detect HBsAg carrier mothers and to immunize their offpsring (Mazel et al., 1984). Obstetricians in four treatment centres were asked to screen all pregnant women for HBsAg at the first antenatal visit. All confirmed $\mathrm{HBsAg}$-positive samples were tested for $\mathrm{HBeAg}$. The serum samples were assayed by radioimmunoassay (Abbott Laboratories, Chicago, IL).

Infants of $\mathrm{HBsAg}$-positive mothers who agreed to passive-active immunization of their newborns received $\mathrm{HBIg}(100-150 \mathrm{IU}$ anti-HBs $/ \mathrm{ml}$ or $300 \mathrm{IU}$ anti-HBs/ml, Central Laboratory of the Netherlands Red Cross Blood Transfusion Service) at birth and active immunization according to several dose and time schedules. Cord blood and blood samples from infants were regularly tested for $\mathrm{HBsAg}$ (Ausria II, Abbott) and anti-HBs (Ausab, Abbott) until at least 12 months of age.

Three hundred and two HBsAg-positive women were identified and delivered over a 7-year period in the two university hospitals participating in the vaccination trial. Both hospitals act as centres for prenatal diagnosis. Amniocentesis or CVS is offered to women of advanced maternal age $(\geq 36$ years) or with a history of fetal chromosomal anomaly or neural tube defects.
At the start of the vaccination programme, the potential risks of transmitting the hepatitis B virus through transplacental leakage caused by invasive diagnostic procedures were unknown. Since no records were kept on invasive testing for prenatal diagnosis in HBsAg-positive pregnant women, we performed a retrospective study of the files of HBsAg-positive women who had their newborn infants immunized within the trial. If prenatal genetic testing had been performed, this was followed by data collection on the sampling procedure and pregnancy outcome. In addition, the HBV DNA levels of the HBsAg carrier mothers who had prenatal diagnosis performed were assayed quantitatively by HBV DNA assay (Abbott), since at present it is thought that the HBV DNA levels of the HBsAg carrier mothers are a better marker for infectivity than $\mathrm{HBeAg}$ (Lee et al., 1986). Intrauterine HBV infection was defined as the occurrence of HBsAg in cord blood and in the subsequent blood samples of infants.

\section{RESULTS}

Invasive prenatal diagnosis was carried out in 18 of the 302 women found to be HBsAg-positive. Of $40 \mathrm{HBsAg}$-positive women aged 36 years or older, only six (15 per cent) had undergone prenatal diagnosis. In another two women aged over 36 years, prenatal diagnosis was not carried out because they were HBsAg-positive. In the other 12 women, prenatal diagnosis was performed for reasons other than maternal age. Of the 18 $\mathrm{HBsAg}$-positive women, two were also $\mathrm{HBeAg}$ positive. One $\mathrm{HBeAg}$-positive woman had high levels of HBV DNA $(61 \mathrm{pg} / \mathrm{ml})$. The other HBeAgpositive woman had an acute HBV infection at the time that she underwent prenatal diagnosis but her blood sample was not available for additional HBV DNA testing. All other women were HBV DNA-negative.

Amniocentesis was performed in 17 cases and CVS in the remaining case. Indications for prenatal diagnosis, $\mathrm{HBeAg}$ status of the women, maternal and gestational age, and pregnancy outcome are presented in Table I. Amniocentesis was performed at 15.4-18 weeks' gestation; one woman, however, underwent amniocentesis at 30 weeks' gestation because multiple malformations were identified by ultrasound. CVS was performed at 10 weeks' gestation. No transplacental amniocentesis was performed and the liquor samples showed no 
Table I-Characteristics of the HBsAg-positive women and the prenatal procedures carried out

\begin{tabular}{|c|c|c|}
\hline & Amniocentesis $*, n=17(\%)$ & Chorionic villus sampling, $n=1$ \\
\hline \multicolumn{3}{|l|}{ Indication } \\
\hline Maternal age & $6(35 \cdot 3)$ & - \\
\hline Other & $11(64 \cdot 7)$ & 1 \\
\hline \multicolumn{3}{|l|}{$\mathrm{HBeAg}$ status } \\
\hline HBeAg-positive & $2(11 \cdot 8)$ & - \\
\hline HBeAg-negative & $13(76.4)$ & 1 \\
\hline Unknown & $2(11 \cdot 8)$ & - \\
\hline \multicolumn{3}{|c|}{ Duration of gestation } \\
\hline First trimester & - & 1 \\
\hline Second trimester & 16 & - \\
\hline Third trimester & 1 & - \\
\hline \multicolumn{3}{|l|}{ Pregnancy outcome } \\
\hline Termination & $3(17 \cdot 6)$ & - \\
\hline Liveborn & $14(82 \cdot 4)$ & 1 \\
\hline
\end{tabular}

*Not transplacental.

signs of blood staining. The woman who had an acute hepatitis B infection and was both HBsAgand $\mathrm{HBeAg}$-positive at the time of amniocentesis displayed a low degree $\mathrm{HBsAg}$-positive liquor (van Os et al., 1991). In all other cases, amniotic fluid was not tested for HBsAg.

The pregnancy was terminated in three cases because of anencephaly (14.6 weeks) or multiple malformations (18.4 and 31 weeks). These women were all $\mathrm{HBsAg}$-positive but $\mathrm{HBeAg}$-negative. The remaining 15 pregnancies were uneventful and resulted in the delivery of 15 healthy infants. The mean gestational age for livebirths was $39 \cdot 1 \pm 2 \cdot 3$ weeks (range 32-42 weeks). The median birth weight was $3558 \pm 722 \cdot 6 \mathrm{~g}$ (range $1660-4920 \mathrm{~g}$ ). None of the neonatal blood samples was HBsAgpositive $(0 / 15 ; 95$ per cent confidence interval $0-21 \cdot 8$ ). All infants were HBsAg-negative at the age of 3 months and thereafter. At the age of 12 months, they had developed protective levels of anti-HBs following active immunization.

\section{DISCUSSION}

We have presented the outcome of invasive prenatal diagnosis in 15 women who were $\mathrm{HBsAg-}$ positive at the time of the procedure. All women, including those highly infective during invasive testing, gave birth to a healthy infant without signs of intrauterine $\mathrm{HBV}$ infection. $\mathrm{HBsAg}$ positivity within the first months of life despite immunoprophylaxis at birth may be due to infection acquired in utero (Ohto et al., 1987). The patient population, however, was selected and numbers may be too small to declare invasive prenatal diagnosis in $\mathrm{HBsAg}$-positive women completely safe. The upper unit of the 95 per cent confidence limit on a stroke rate of 0 per cent among 15 patients is 22 per cent.

The exact mode of intrauterine transmission of HBV from the mother to the infant is unknown. In cases of invasive testing involving the chorion or the placenta, HBV may be directly transmitted from maternal to fetal blood. Another possible route of $\mathrm{HBV}$ transmission may be the swallowing of HBsAg-contaminated amniotic fluid by the fetus. So, on a theoretical basis it seems safe to avoid transplacental procedures and/or CVS in HBsAg carrier pregnant women and certainly in the more infectious subgroup which is also HBeAg-positive or has high levels of HBV DNA. Any vascular area in the uterine wall should be avoided so as to limit the contamination of the amniotic cavity with maternal blood.

Several important factors associated with maternal-fetal transmissions of HBV need further discussion. A likely explanation for the absence of HBV infections in our study is that direct blood to blood contact did not take place. By comparison, HBV transmission by needle-stick has been shown to vary between 5 and 11 per cent (Grady et al., 
1978; Seeff et al., 1978). The risk of infection depends on the level of infectivity of the injected material (Alter et al., 1976). After a percutaneous exposure to $\mathrm{HBeAg}$-positive blood, the risk of transmission increases to approximately 30 per cent (Grady et al., 1978; Seeff et al., 1978). Since only two women may be considered as highly infective, the risk for the development of HBV infection through microleakage of maternal blood after invasive prenatal diagnostic techniques may have been negligible. The only woman who underwent CVS was $\mathrm{HBeAg}$-negative, so no conclusions can be drawn on the safety of this procedure in $\mathrm{HBeAg}$-positive women.

Wong et al. (1980) performed third-trimester amniocentesis in $61 \mathrm{HBsAg}$-positive women and found $\mathrm{HBsAg}$ in 16 (26 per cent) liquor samples. Amniocentesis in HBsAg-positive women did not affect the incidence of $\mathrm{HBsAg}$ in 1-month-old babies ( 14.3 per cent), in comparison with a control group ( 5 per cent) who did not have amniocentesis $(P>0 \cdot 1)$. However, a positive correlation $(P=0.04)$ was reported in $\mathrm{HBeAg}$-positive mothers between the presence of $\mathrm{HBsAg}$ in amniotic fluid and the finding of antigen in newborns at the age of 1 month. The authors concluded that amniocentesis should be discouraged if mothers are HBsAgand $\mathrm{HBeAg}$-positive.

The risk of infection also depends on the quantity of injected material. Introduction of an amount as small as $10^{-8} \mathrm{ml}$ of $\mathrm{HBeAg}$-positive blood is sufficient for infection (Shikata et al., 1977). The incidence of maternal-fetal transfusion in the literature varies from 2 to over 50 per cent, depending on complications during pregnancy and the methods of testing used (Schröder, 1975). The overall risk of fetal red cells entering the maternal circulation following amniocentesis was 10 per cent according to Sebring and Polesky (1990), and considerable fetal-maternal haemorrhage after CVS was described by Mantingh (1988), who found increased concentrations of maternal serum alpha-fetoprotein in 60 per cent of the blood samples. The degree of maternal-fetal transfusion and disruption of placental barriers as a result of invasive testing for prenatal diagnosis, however, is not known.

Transmission of HBV by the oral route has been documented in an experimental setting but appeared far less effective than the parenteral route (Krugman and Giles, 1970). In the natural situation, the risk of infection is considered to be very low. This finding is partly based on experience in endoscopy; HBV infection through endoscopy appeared low or non-existent (Villa et al., 1984). As 20 per cent of placental perforations are associated with bloody taps (Kappel et al., 1987), ingestion of $\mathrm{HBs} A g$-contaminated amniotic fluid by the fetus is therefore not likely to be an important mode of transmission. However, transplacental procedures were not performed in our HBsAg-positive women. In the one woman who had weakly HBsAg-positive amniotic fluid, contamination with maternal blood is the most likely explanation.

Finally, it is suggested that the fetal organs only become susceptible to HBV during the third trimester of pregnancy (Gerety and Schweitzer, 1977). The risk of the hepatitis B virus being transmitted from a freshly infected mother to her fetus was 70 per cent during the third trimester, but appeared to be virtually non-existent in women who were infected at an earlier stage (Schweitzer, 1975). Failure to transmit HBV from the mother to the fetus before the third trimester may be due to failure of the HBV to pass the placenta or failure of the fetus to support the HBV. For instance, no integration of HBV DNA was detected in fetal liver cells from 48 terminated pregnancies after 20-32 weeks of gestation ( $\mathrm{Li}$ et al., 1986). Also, conception and development of the pre-embryo in an $\mathrm{HBsAg-positive} \mathrm{woman}$ occur in a potentially infectious medium, and even the accidental HBV exposure of pre-embryos to a contaminated culture medium during in vitro fertilization procedures did not result in intrauterine infections (van Os et al., 1991).

Although data are scarce, the available information may support the idea that HBV will not harm the fetal liver early in pregnancy. The present uncertainties, however, point to the need for a more careful and considered approach to the widespread use of invasive prenatal diagnostic techniques in HBsAg-positive women. For highly infectious women ( $\mathrm{HBeAg}$-positive or HBV DNApositive), a firm conclusion on the safety of invasive prenatal diagnosis, especially CVS, cannot be drawn. Perhaps, extensive studies in countries with a high prevalence of HBV may solve some of these issues.

\section{ACKNOWLEDGEMENTS}

We would like to thank Y. A. M. Weber and $\mathrm{C}$. Kerkhof for performing the laboratory tests. We are indebted to J. W. Wladimiroff and 
F. Los for their helpful comments regarding the manuscript.

\section{REFERENCES}

Alter, H.J., Seeff, L.B., Kaplan, P.M., McAuliffe, V.J., Wright, E.C., Gerin, J.L., Purcell, R.H., Holland, P.V., Zimmerman, H.J. (1976). Type B hepatitis: the infectivity of blood positive for e antigen and DNA polymerase after accidental needlestick exposure, $N$. Engl. J. Med, 295, 909-913.

Beasley, R.P., Trepo, C., Stevens, C.E., Szmuness, W. (1977). The e antigen and vertical transmission of hepatitis B surface antigen, Am. J. Epidemiol, 105, 94-98.

Beasley, R.P., Hwang, L.Y., Lin, C.C., Leu, M.L., Stevens, C.E., Szmuness, W., Chen, K.P. (1982). Incidence of hepatitis B virus infections in preschool children in Taiwan, $J$. Infect. Dis., 146, 198-204.

Gerety, R.J., Schweitzer, I.L. (1977). Viral hepatitis type $B$ during pregnancy, the neonatal period, and infancy, J. Pediatr., 90, 368-374.

Grady, G.F., Lee, V.A., Prince, A.M., Gitnick, G.L., Fawaz, K.A., Vyas, G.N., Levitt, M.D., Senior, J.R., Galambos, J.T., Bynum, T.E., Singleton, J.W., Clowdus, B.F., Akdamar, K., Aach, R.D., Winkelman, E.I., Schiff, G.M., Hersch, T. (1978). Hepatitis B immune globulin for accidental exposures among medical personnel: final report of a multicenter controlled trial, J. Infect. Dis., 138, 625-638.

Kappel, B., Nielsen, J., Brogaard Hansen, K., Mikkelsen, M., Therkelsen, A.A.J. (1987). Spontaneous abortion following mid-trimester amniocentesis. Clinical significance of placental perforation of bloodstained amniotic fluid, Br. J. Obstet. Gynaecol, 94, 50-54.

Krugman, S., Giles, J.P. (1970). Viral hepatitis-new light on an old disease, J. Am. Med. Assoc., 212, 1019-1029.

Lee, A.K.Y., Ip, H.M.H., Wong, V.C.W. (1978). Mechanisms of maternal-fetal transmission of hepatitis B virus, $J$. Infect. Dis., 138, 668-671.

Lee, S.D., Lo, K.J., Wu, J.C., Tsai, Y.T., Wang, J.Y., Ting, L.P., Tong, M.J. (1986). Prevention of maternal infant hepatitis B virus transmission by immunization: the role of serum hepatitis B virus DNA, Hepatology, 6, 369-373.

Li, L., Sheng, M.H., Tong, S.P., Chen, H.Z., Wen, Y.M. (1986). Transplacental transmission of hepatitis B virus, Lancet, 2, 872.

Lin, H.H., Lee, T.Y., Chen, D.S., Sung, J.L., Ohto, H., Etoh, T., Kawana, T., Mizuno, M. (1987). Transplacental leakage of HBeAg-positive maternal blood as the most likely route in causing intrauterine infection with hepatitis B virus, J. Pediatr., 111, 877-881.

Mantingh, A. (1988). On CVS. Early experience with chorionic villus sampling (CVS) in the north of The Netherlands, Ph.D. thesis, Groningen.
Mazel, J.A., Schalm, S.W., de Gast, G.C., Nuijten, A.S.M., Heijtink, R.A., Botman, M.J., Bänffer, J.R.J., Gerards, L.J., Zwijnenberg, J., Mettau, J., Wladimiroff, J.W., Fetter, W.P.F. (1984). Passiveactive immunization in neonates of HBsAG-positive carrier mothers. Preliminary observations, Br. Med. J., 288, 513-515.

Ohto, H., Lin, H.H., Kawana, T., Etoh, T., Tohyama, H. (1987). Intrauterine transmission of hepatitis B virus is closely related to placental leakage, $J$. Med. Virol., 21, 1-6.

Schalm, S.W., Mazel, J.A., Gast de, G.C., Heijtink, R.A., Botman, M.J., Bänffer, J.R.J., Gerards, L.J., Zwijnenberg, J., Fetter, W.P.F., Nuijten, A.S.M., Wladimiroff, J.W., Christiaens, G.C.M.L. (1989). Prevention of hepatitis B infection in newborns through mass screening and delayed vaccination of all infants of mothers with hepatitis B surface antigen, Pediatrics, 83, 1041-1047.

Schröder, J. (1975). Transplacental passage of blood cells, J. Med. Genet., 12, 230-242.

Schweitzer, I.L. (1975). Vertical transmission of the hepatitis B surface antigen, Am. J. Med. Sci., 270, 287-291.

Sebring, E.S., Polesky, H.F. (1990). Fetomaternal hemorrhage: incidence, risk factors, time of occurrence and clinical effects, Transfusion, 30, 344-357.

Seeff, L.B., Wright, E.C., Zimmerman, H.J., Alter, H.J., Dietz, A.A., Felsher, B.F., Finkelstein, J.D., GarciaPont, P., Gerin, J.L., Greenlee, H.B., Hamilton, J., Holland, P.V., Kaplan, P.M., Kiernan, T., Koff, R.S., Leevy, C.M., McAuliffe, V.J., Nath, N., Purcell, R.H., Schiff, E.R., Schwartz, C.C., Tamburro, C.H., Vlahcevic, Z., Zemel, R., Zimmon, D.S. (1978). Type $B$ hepatitis after needlestick exposure: prevention with hepatitis B immune globulin: final report of the Veterans Administration Cooperative Study, Ann. Intern. Med., 88, 285-293.

Shikata, T., Karasawa, T., Abe, K., Uzawa, T., Suzuki, H., Oda, T., Imai, M., Mayumi, M., Moritsugu, Y. (1977). Hepatitis B e antigen and infectivity of hepatitis B virus, J. Infect. Dis., 136, 571-576.

Stevens, C.E., Beasley, R.P., Tsui, J., Lee, W.C. (1975). Vertical transmission of hepatitis $B$ antigen in Taiwan, N. Engl. J. Med., 292, 771-774.

Stevens, C.E., Neurath, R.A., Beasley, R.P., Szmuness, W. (1979). $\mathrm{HBeAg}$ and anti-HBe detection by radioimmunoassay: correlation with vertical transmission of hepatitis B virus in Taiwan, J. Med. Virol., 3, 237-241.

Stevens, C.E., Taylor, P.E., Tong, M.J., Toy, P.T., Vyas, G.N., Nair, P.R., Weissman, J.Y., Krugman, S. (1987). Yeast recombinant hepatitis B vaccine. Efficacy with hepatitis B immune globulin in prevention of perinatal hepatitis B virus transmission, J. Am. Med. Assoc., 257, 2612-2616.

van Os, H.C., Drogendijk, A.C., Fetter, W.P.F, Heijtink, R.A., Zeilmaker, G.H. (1991). The influence 
of contamination of culture medium with hepatitis B virus on the outcome of in vitro fertilization pregnancies, Am. J. Obstet. Gynecol., 165, 152-159.

Villa, E., Pasqyinelli, C., Rigo, G. et al. (1984). Gastrointestinal endoscopy and HBV infection: no evidence for a causal relationship, Gastrointest. Endosc., 30, 15-17.
Wong, V.C.W., Lee, A.K.Y., Ip, H.M.H. (1980). Transmission of hepatitis $B$ antigens from symptom free carrier mothers to the fetus and the infant, $B r . J$. Obstet. Gynaecol., 87, 958-965. 